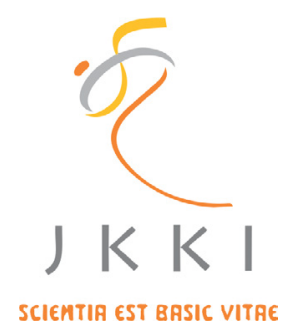

Jurnal Kedokteran dan Kesehatan Indonesia

Indonesian Journal of Medicine and Health

Journal homepage : https://journal.uii.ac.id/JKKI

\title{
Developing of need assessment on policy makers and stakeholders applying a non-smoking area program at district office of Dukun, Magelang regency
}

\author{
Punik Mumpuni Wijayanti*1, Arif Rahmat Kurnia², Edi Soeharso ${ }^{3}$ \\ ${ }^{1}$ Department of Public Health, Faculty of Medicine, Universitas Islam Indonesia, Yogyakarta, Indonesia \\ ${ }^{2}$ Department of Public Health, Faculty of Sports Science, Universitas Negeri Semarang, Semarang, Indonesia \\ ${ }^{3}$ Public Health Office of Dukun District, Magelang, Indonesia
}

Original Article

\begin{tabular}{l}
\hline \\
\hline ARTICLE INFO \\
\hline Keywords: \\
Dukun District Office, \\
smoking habit, \\
non-smoking area \\
\hline *Corresponding author: \\
punik_m@yahoo.com \\
\hline DOI:10.20885/JKKI.Vol11.Iss1.art9 \\
\hline History: \\
Received: June 18, 2017 \\
Accepted: September 26, 2018 \\
Online: April 30, 2020 \\
\hline Copyright @2020 Authors. \\
This is an open access article \\
distributed under the terms \\
of the Creative Commons At- \\
tribution-NonCommercial 4.0 \\
International Licence (http:// \\
creativecommons.org/licences/ \\
by-nc/4.0/).
\end{tabular}

\section{ABSTRACT}

Background: A smoking habit mostly has spread to almost groups of societies in Indonesia. This habit tends to increase among children and adolescents. Rights to access fresh air free from smoking have been widely discussed at various world meetings. Therefore, it is necessary to have an in-depth study to increase non-smoking areas in public areas.

Objective: This study is to develop a need assessment on policy makers and related stakeholders applying a non-smoking area program (in Indonesia it is called KTR/Kawasan Tanpa Rokok) at District Office of Dukun, Magelang Regency, Central Java.

Methods: This study was an observational study with a qualitative approach. Its respondents were determined purposively focusing on the Head of Dukun District, some officials of the District, and its visitors.

Results: This study found that a majority of respondents understood effects and impacts of smoking to their health. They requested an issuance of official letter for a non-smoking area. The Head of the District has issued a smoking ban for its officials and employees. This issuance was important to increase comfort of its visitors, employees, and officials. In addition, it could make the Head easier to develop derivative regulations.

Conclusion: A defined regulation is necessary to apply the non-smoking area program. A regulation from the Regent is highly suggested, but decisions from related agencies can be considered sufficient. The government and related stakeholders should immediately make a local regulation so that the program can be widely applied in the Dukun District.

Latar Belakang: Kebiasaan merokok di masyarakat sudah meluas pada hampir seluruh kelompok masyarakat di Indonesia. Kebiasaan inicenderung meningkat di kalangan anak dan remaja. Hal iniselain dikarenakan oleh gencarnya promosi rokok di berbagai media massa, juga disebabkan oleh budaya dan lingkungan yang selalu mendukung adanya perilaku merokok disetiap keadaan. Hak untuk udara yang bersih dari asap rokok sekarang telah banyak dibahas di berbagai pertemuan dunia. Oleh karena itu perlu adanya kajian mendalam untuk meningkatkan daerah kawasan tanpa rokok pada areal publik.

Tujuan: Mengembangkan need assesment pada para penentu kebijakan dan stakeholder terkait dalam pengembangan program kawasan tanpa rokok di tempat kerja yaitu di kantor kecamatan Dukun, kabupaten Magelang Jawa Tengah

Metode: Penelitian ini merupakan sebuah penelitian observasional dengan pendekatan kualitatif menggunakan teknik qualitative content analysis. Penentuan responden dilakukan secara purposif pada 
camat, pegawai kecamatan, dan pengunjung.

Hasil: Mayoritas responden mengetahui dampak dan efek samping dari rokok dipandang dari segi kesehatan. Seluruh responden meminta diadakannya surat edaran resmi tentang kawasan tanpa rokok. Camat mengeluarkan larangan merokok untuk pegawai kecamatan. Hal ini penting untuk meningkatkan kenyamanan pengunjung, pegawai, dan pejabat di kecamatan serta mempermudah camat dalam menyusun peraturan turunan.

Kesimpulan: Hal yang paling dibutuhkan dalam penerapan KTR adalah peraturan yang jelas. Peraturan dari bupati sangat diharapkan, namun surat keputusan dari dinas terkait dianggap sudah cukup memenuhi. Pemerintah dan stakeholder terkait harus segera membuat peraturan daerah sehingga KTR dapat diaplikasikan secara luas di kecamatan Dukun.

\section{INTRODUCTION}

The basic health research in 2010 estimated that prevalence of smokers was around $34.7 \%$ (or more than one per three of Indonesia's population) although rights to breathe fresh free from smoking have been a global concern. ${ }^{1}$ In fact, WHO (world health organization) has predicted that smoking-related diseases will become a global health problem. ${ }^{2}$ Therefore, WHO has developed a global work through FCTC (framework convention on tobacco control) including public health sectors. The WHO general assembly adopted this convention in May 2003 and became a significant action in February 2005, hosting more than 180 countries as part of the FCTC. The results of the FCTC convention were international legal instruments as means of protection to reduce tobacco uses and to become a global standard for tobacco control. ${ }^{3,4}$

Tobacco control support center (TCSC), ikatan ahli kesehatan Indonesia/Indonesian association of public health experts (IAKMI) in collaboration with Southeast Asia tobacco control alliance (SEATC) and WHO Indonesia reported four best policy alternatives to assist tobacco issues. The policy includes raising taxes by $65 \%$ of retail prices, including all forms of cigarette advertisements, implementing 100\% no-smoking areas in public places, in workplaces and in education environment, increasing the transfer of smoking and adding images of smoking effects. Besides, establishment of non-smoking areas has been pursued by various parties including both government and private institutions; either local, national or international institutions. ${ }^{5}$

Developing tobacco control policies has also been addressed in Indonesia. One of policies is a regulation governing protection of societies. 6 According to the health act No. 36/2009, concerning tobacco products as an addictive substance for health, especially article 115 (paragraph 2) states that regional governments are obliged to regulate non-smoking areas in its territory. In Article 119 (paragraph 2) issued in 115 , a fine of 50,000,000 (fifty million rupiahs) is imposed. ${ }^{7}$

Working of developing of non-smoking areas (called as KTR/kawasan tanpa rokok in Indonesia), dukun District, Magelang regency, a location of this study, has applied 4 program management procedures, namely: need assessment (community analysis \& targeted assessment), planning, implementation and evaluation. The need assessment is really needed to organize a specific program. In this case, the researchers will examine various existing data sources and various relevant stakeholders to formulate a particular program.

This study aims to develop an assessment plan for policymakers and stakeholders involved in the KTR program at the district office of Dukun, Magelang regency. The office is chosen by a recommendation of the head of puskemas (community health centre) of Dukun District, and the district has not had a non-smoking area.

Specific purposes of this study are to study relevant needs of policymakers and stakeholders and to determine supports of policymakers and stakeholders in applying the KTR program in the Dukun District Office. Moreover, it is hopefully can be used as an advocacy to apply the non-smoking area program in other public places. 


\section{METHODS}

\section{Research design}

This research was an observational study with a qualitative approach. It was intended to determine supports of policymakers and stakeholders involved in developing the nonsmoking are program, KTR, at district office of Dukun, Magelang regency, Central Java.

\section{Subject and location}

This study involved 6 respondents (subjects) including officials, employees and visitors at the Dukun district office. The respondents were determined by using a purposive method. Previously, researchers already had a list of prospective respondents based on several considerations. In order to get more prospective respondents, the researchers were assisted by local people who know the respondents. After getting several data, researchers used a snowball effect method. This was conducted to attract more prospective respondents so that the researchers could observe issues in this study more thoroughly.

\section{Object}

This study is to investigate social situation in implementing the non-smoking area program, KTR, in the Dukun district office, Magelang regency. This included in-depth observations of activities and their people (actors) that are in the district office (place).

\section{Data type and resource}

This study focused on primary data sources. The primary data were obtained from results of the in-depth interviews with the respondents.

\section{Instruments}

Instruments in this qualitative research were the researchers themselves. Validation of the researchers as an instrument included validation of understanding of qualitative research methods, mastering the field of this study, and being ready for this study. The validation is conducted by the researchers themselves through self-evaluation on understanding of qualitative methods, mastering of theory and insight into the field study, as well as readiness and provision for the study. ${ }^{8}$ To support the data collection process, instruments during the interview included recording equipment, stationery, notebooks, and camera.

\section{Data collecting technique}

Researchers conducted non-participatory observation to collect data in this study by determining respondents purposively. In this technique, researchers were outside activities as audiences. Researchers arrived at office hours of the district office and returned when the data obtained were saturated. Interviews were conducted by using in-depth interview method in an unstructured manner. The interview guide used outlines of issues that would be questioned. Documentation was by collecting photos and notes at the time of the data collection. This study used triangulation of sources to determine the respondents, meaning that obtained information was from a various different sources (respondents).

\section{Data analysis technique}

This study used qualitative content analysis technique. The researchers processed the data, divided the data into manageable units, synthesized the data, found patterns of the data, discovered what is important and what is learned, and decided what can be told to others. ${ }^{9}$ In this study, the analysis was conducted interactively and continuously until it was complete, and the data became saturated.

\section{Ethics}

Informed consent about mechanism or process of this study was given to all respondents before it was conducted; therefore, they would understand their roles and could participate voluntarily without coercion or pressure. After getting an explanation, they were given an approval sheet to be signed in participating in this study. Researchers also maintained research ethics by applying anonymity and confidentiality. The anonymity was by giving a 
number (code) for each data. Researchers also guaranteed the confidentiality of information provided by the respondents.

\section{RESULTS}

There were 6 respondents interviewed through in-depth interviews. Respondents 1 and 2 are Mr. A, (40 years old, male) and Mr. B (55 years old, male). Both are a structural employee in the Dukun District Office with a non-smoking status. Respondent 3 is $\mathrm{Mr}$. C (54 years old, male) with a smoking status. Respondent 4 is Mr. D (38 years old, male), and he is a visitor of the Dukun District Office with a smoking status. Respondent 5 is Mrs. E (45 years old, female), and she is a visitor with a non-smoking status. Respondent 6 is Mr. F (53 years old, Male), and he is the head of Dukun District Office with a smoking status.

\section{Perception of smoking behavior and KTR}

Perception can be defined as a process; a person selects, organizes, and interprets a stimulus into a meaningful and comprehensive world picture. The stimulus is any input that can be captured and received by human senses, such as eyes, ears, mouth, nose, and skin. ${ }^{7}$ Based on results of the interviews, this study found that most of all respondents understand that smoking is harmful for health. Some respondents added that smoking is a waste according to islamic teachings.

Table 1. Research Subject Characteristics

\begin{tabular}{cccccc}
\hline Number & \multicolumn{1}{c}{ Code } & Sex & Age & Employment status & Smoking status \\
\hline 1. & Mr. A (Respondent 1) & Male & 40 & District staff & No \\
2. & Mr. B (Respondent 2) & Male & 55 & District staff & No \\
3. & Mr. C (Respondent 3) & Male & 54 & Visitor & Yes \\
4. & Mr. D (Respondent 4) & Male & 38 & Visitor & Yes \\
5. & Mrs. E (Respondent 5) & Female & 45 & Visitor & No \\
6. & Mr. F (Respondent 6) & Male & 53 & Head of district & Yes \\
\hline
\end{tabular}

from the danger aspects I know the dangers of smoking, but this habit cannot be abandoned. Because we serve and contact the people, the society, we make a prohibition not to smoke in the service room. If some employees are found smoking, they will be considered unethical and inappropriate for others to see ... (Respondent 6).

In fact, there has been no official issuance about a non-smoking are, so the head of district has issued a smoking ban initiative for the employees. This makes most employees not smoke in service rooms, even though they have difficulty to stop smoking. By the issuance, a definite solution is also necessary for who smokes.
I know cigarettes are dangerous, but I also want a solution for smokers like me. It feels bad if smoking is forbidden without a particular place to smoke, while we ourselves have difficulty to stop smoking ... (Respondent 4).

This shows that the majority of respondents stated that smoking is not good for health or harmful for health.

........ I know there is a smoking ban, but economically smoking is beneficial. Passive smokers will also get double dangers of active smokers, but I do not know details of the dangers. I just feel uncomfortable when someone smokes around me........ (Respondent 2). 
Actually, it is universally understood by both smokers and non-smokers that smoking is not good for health. The cigarette and smoking are not only viewed in terms of health, but also in terms of economy \& community habits. Although they understand the danger of smoking, it is still done as well. In addition, who come to the Dukun District are limited not only to employees, but also to all people, so that the no-smoking area regulation will not be effective if it is not accompanied by definite rules and sanctions.

\section{Stakeholder attitudes towards smoking behaviour and non-smoking area (KTR)}

Attitude shows an individual's assessment of a thing, illustrates an individual likes or dislikes and forms a basis for behaviour. Attitude to smoke and the attitude of anti-smoking are still pros and cons in addressing the no-smoking area in the office. The KTR program at the office was agreed by a majority of respondents. However, there are still a lot of steps and strategies to make it happen. KTR can increase the comfort of visitors and employees in the office. There are respondents who think that smoking is an unclean act and less understanding and care for the cleanliness of the environment and themselves.

I agree there is a no-smoking area because it makes people more comfortable to come to the district office. This must be supported by an adequate smoking area because smoking is part of human rights ... (Respondent 5).

Most of respondents still smoke, so they hope for a representative smoking area.

I agree with the issuance of a nonsmoking area, but a location where smokers are allowed to smoke must be determined. Without a particular location to smoke, the non-smoking area program will never be effective....... (Respondent 4).

Most respondents are positive or supportive if there is a non-smoking area in islamic boarding schools. This has been disclosed by residents, employees, and the head of the district who served in the office.

Definite rules from the regent will make easier for us to maximize the non-smoking area program. I am ready to make strict regulations if supported by the Regent ...(Respondent 6).

\section{DISCUSSION}

There is no doubt that the dangers of smoking are at the level of destruction for a nation. Considering the advance of antismoking campaign in the west, many cigarettemanufacturing companies are directing their marketing to developing countries that consume more than $52 \%$ of cigarette in the world. ${ }^{8}$ The WHO reported that the death rate caused by smoking had reached 2.5 million people per year. Meanwhile, a number of victims by the smoking case in the United States in 1987 were 350,000 , and in Britain were 100,000 in $1997 .{ }^{9}$ The number of victims and sufferers of diseases caused by the smoking are increasing. It has been presumed that $30 \%$ to $40 \%$ of smokers get addicted by the age of less than fifteen years. ${ }^{10}$

When viewed from social and cultural aspects, the smoking habit seems become a social phenomenon that is quite extraordinary but does not receive much attention. Being realized or not, some become addicted to smoke, and others are interested to smoke too. When they become addicted, they usually refuse to stop smoking by various reasons. This addictive effect is one of factors of smoking behaviour in the district office. ${ }^{11}$

Regulations regarding smoking bans in public spaces in Indonesia have also never been definitively confirmed. In addition, a majority of smokers in Indonesia are not discipline. Although there are smoking bans in public spaces, some smokers violently break them. They have already understood that cigarette smoke can also cause people around them as passive smokers, but they do not seem to care about the passive smokers and their environment. Developing the KTR program is 
one of the most rational program to guarantee visitors' comfort in the Dukun district office.

\section{CONCLUSION}

This study showed that all respondents including relevant stakeholders have good perceptions related to the dangers of smoking, the dangers of smoking for passive smokers, and the non-smoking program (KTR) in the Dukun district office, Magelang regency, Central Java Province.

Most respondents had very good attitudes or responses to the no-smoking area program. Some respondents appreciated their colleagues or visitors who smoke, but most respondents strongly agreed to the non-smoking area program. The majority of who has authority in the office strongly agreed to the program with a humanist strategic approach respecting different opinion before it was implemented.

Advantages of this study is to show a specific phenomenon that may not appear in quantitative research. A limitation of this study is its inability to demonstrate significant relationship of factors in this study. It can go further to study relationships between perceptions and attitudes of residents of the Dukun District in applying the non-smoking area.

\section{CONFLICT OF INTEREST}

The researchers do not have a conflict of interest with all parties involved in this study and in its results.

\section{ACKNOWLEDGEMENT}

Researchers thank to the Faculty of Medicine of UII for funding this research. Acknowledgments were also conveyed to all parties who made this research well conducted.

\section{REFERENCES}

1. Balitbangkes. Riset kesehatan dasar (RISKESDAS) 2010. Jakarta: 2010.

2. Martinasek MP, McDermott RJ, Martini
L. Waterpipe (hookah) tobacco smoking among youth. Current Problems in Pediatric and Adolescent Health Care. 2011; 41(2): 34-57

3. Exter A Den. Letter to the editor first fctc case in the Netherlands. Public Health. 2016; 127(10): 970-1.

4. Adebiyi AO, Uchendu OC, Bamgboye E, Ibitoye 0 , Omotola B. Perceived effectiveness of graphic health warnings as a deterrent for smoking initiation among adolescents in selected schools in southwest Nigeria. Tobacco Induced Diseases. 2016; 14(1): 7.

5. Rosen LJ, Rier DA, Schwartz R, Oren A, Kopel A, Gevman A, et al. Public support for smoke-free areas in Israel: A case for action. Health Policy (New York). 2012; 106(2): 161-8.

6. England LJ, Tong VT, Koblitz A, Kish-Doto J, Lynch MM, Southwell BG. Perceptions of emerging tobacco products and nicotine replacement therapy among pregnant women and women planning a pregnancy. Preventive Medicine Reports. 2016; 4: 481-5.

7. Kemenkes. Peraturan Menteri Kesehatan Republik Indonesia Nomor 40 Tahun 2013 Tentang Peta Jalan Pengendalian Dampak Konsumsi Rokok Bagi Bagi Kesehatan. Menteri Kesehatan Republik Indonesia. 2013; 40: 1-19.

8. Okoli CTC, Pederson A, Rice W. Support for a smoke-free bylaw in parks and on beaches. Health Policy (New York). 2013; 111(2): 127-34.

9. Bilano V, Gilmour S, Moffiet T, D'Espaignet ET, Stevens GA, Commar A, et al. Global trends and projections for tobacco use, 1990-2025: an analysis of smoking indicators from the WHO Comprehensive Information Systems for Tobacco Control. Lancet. 2015; 385(9972): 966-76.

10. Tahlil T, Woodman RJ, Coveney J, Ward PR. The impact of education programs on smoking prevention: a randomized controlled trial among 11 to 14 year olds in Aceh, Indonesia. BMC Public Health. 2013; 13: 367. 
JKKI 2020;11(1):60-66

11. Gökbayrak NS, Paiva AL, Blissmer BJ, Prochaska JO. Predictors of relapse among smokers: Transtheoretical effort variables, demographics, and smoking severity. Addictive Behaviors. 2015; 42: 176-9. 